\title{
THE EFFECTS OF DIFFERENT SOWING TIME AND HARVESTING HEIGHT ON HYDROCYANIC ACID CONTENT IN SOME SILAGE SORGHUM (Sorghum bicolor L.) VARIETIES
}

\author{
Mehmet OTEN* \\ Western Mediterranean Agricultural Research Institute, Department of Field Crops, Antalya, TURKEY \\ *Corresponding author: moten07@hotmail.com
}

Received: 30.03.2017

\begin{abstract}
The objective of this experiment was to determine the hydrocyanic acid (HCN) levels that have poisonous effects on animals, in 4 different sorghum and 1 sudangrass species, which were developed by Batı Akdeniz Agricultural Research Institute and widely used in our country. Experiments were carried out in experimental fields of institute during 2014 and 2015 growing seasons. Rox, Leoti, Early Sumac and Nes sorghum varieties with Gozde 80 sudangrass variety were cultivated as May-June and June-July planted crops in a randomized block design with three replications. Plants were harvested when they reached 40, 80 and $120 \mathrm{~cm}$ heights and they were extracted in order to determine HCN contents. The analysis of variance indicated that there were significant differences in terms of HCN content in all varieties. The HCN levels of varieties were determined in Gozde 80, Early Sumac, Nes, Leoti and Rox in descending order. In the first year, the highest HCN level was determined in Early Sumac variety with $40 \mathrm{~cm}$ harvesting height at the first sowing time, the lowest level was determined in Gozde 80 variety with $120 \mathrm{~cm}$ harvesting height at the second sowing time. In the second year, the highest HCN level was determined in Gozde 80 variety with $40 \mathrm{~cm}$ harvesting height at the first sowing time, the lowest HCN level was determined in Early Sumac variety with $120 \mathrm{~cm}$ harvesting height at the second sowing time. At the end of the experiment, the highest $\mathrm{HCN}$ content was found at the first sowing time with $40 \mathrm{~cm}$ harvesting height.
\end{abstract}

Key words: Harvesting height, Hydrocyanic acid, Silage sorghum, Sowing time

\section{INTRODUCTION}

Sorghum is one of the most used five main products in human and animal nutrition in the world, and it is in fifth place after wheat, corn, rice and barley in terms of cultivation and production (Baytekin et al., 1996). Total sorghum harvesting area 33,1-44.9 million hectares in the world in 2013-2014 years respectively (FAO, 2017). Sorghum is widely used as a silage crops, because it can be harvested more than once during the vegetation period (Tüsüz et al., 1984). Additionally, it is more resistant to drought and diseases than maize (McGinty, 1972) and shows a better development in high temperatures (Okuyucu, 1975).

The Mediterranean region is suitable for the cultivation of various forage crops due to the soil structure and climate. In the researches for the Mediterranean region, it was proved that different harvesting stages had an effect on some silage parameters of sorghum. It is reported that sorghum and sudangrass are more economical than maize as roughage source in the coastal region of Antalya by the reason of they can be harvested at least 3 times, and they have similar nutritional value with maize. Sorghum can be planted as main and second crop, planting time show the differences year by year according to the climatic conditions, therefore especially silage quality, plant development and plant nutrient contents show differences (Oten and Cakmakc1, 2010). There have been several studies about sorghum in Turkey. In studies, hay yield was determined $1273.5-2184.8 \mathrm{~kg}$ $\mathrm{da}^{-1}$ by Mulayim et al. (2009), 3683-4791 $\mathrm{kg} \mathrm{da}^{-1}$ by Tugay (2009), 1908.98 - $2343.41 \mathrm{~kg} \mathrm{da}^{-1}$ by Karadas (2008), $1654 \mathrm{~kg} \mathrm{da}^{-1}$ by Cecen et al. (2005), 1453.40$1975.60 \mathrm{~kg} \mathrm{da}^{-1}$ by Y1lmaz and Hosaflioglu (2000) and 1050 - $1423 \mathrm{~kg} \mathrm{da}^{-1}$ by Soya (1999). Forage yield of sorghum was determined $5355-8173 \mathrm{~kg} \mathrm{da}^{-1}$ by Gul and Baytekin (1999), 7000-10000 kg da ${ }^{-1}$ in irrigated conditions and $1500 \mathrm{~kg} \mathrm{da}^{-1}$ in arid conditions by Aç1kgoz (2001). Despite of the high yield potential and high tolerance in different regions and climatic conditions, under unsuitable conditions, sorghum and sudangrass contain different ratios of HCN (Hydrocyanic acid / Cynaide / Prussic Acid), which is a toxic substance. These unsuitable conditions can be exemplified as heavy nitrogen fertilization, drought, acidic soils, phosphorus deficiency in the soil, low heat and frost. If the plant is exposed to these unsuitable conditions, it accumulates nitrate in abnormal rate in the stem. Afterwards, Nitrate 
becomes toxic for animals by transforming into nitrite. Thus, more than $0.5 \%$ nitrate in dry matter is dangerous. Hydrocyanic acid does not exist in large quantities in the plant as long as plant is vigour. Plant cells contain glycosides (dhurrin) and enzymes (emulsion) separately during growing period. When the plant cells are damaged by harvesting or grazing, glycosides and enzymes are combined and transformed into $\mathrm{HCN}$ as a result of chemical reaction. The highest amount of glycoside is found in young plants and leaves, and $\mathrm{HCN}$ concentration decreases when plant height increases and maturation of plant progresses. HCN level decreases to the lowest level at the beginning of flowering for sudangrass, and at the milk stage for silage sorghum. Considering these toxic substances reduce when sorghum and sudangrass grow up, plant height should be $70-100 \mathrm{~cm}$ for grazing or harvesting (Ac1kgoz, 2001; Haque and Bradbury, 2001; Wheeler et al., 1990; Tusuz et al., 1984; Langer and Hill, 1982;). Isakov and Basova (1973) reported that young leaves and plants contains more $\mathrm{HCN}$ than old leaves. Moreover, while different amounts of nitrogen treatments increase the level of $\mathrm{HCN}$ 50-180 ppm, phosphorus deficiency and low temperatures increase the HCN level. Aziz-Abdel and Abdel-Gwad (2008) and Pholsen and Somsungnoen (2004) indicated that, while nitrogen fertilization increases the rate of $\mathrm{HCN}$ level, it reduces the sugar rate. Williams and James (1983) determined that herbicide treatment (2,4-D and 2,4,5-T) increases the level of HCN in sorghum. Lang (2001) stated dangerous levels of $\mathrm{HCN}$ concentrations of fresh forage as $<150 \mathrm{ppm}$ is low, 150-200 ppm is medium and $>200$ is high for livestock (Table 3). Koch and Paisley (2012), stated dangerous levels of $\mathrm{HCN}$ in forages; less than $600 \mathrm{ppm}$ is not toxic, $600-1800 \mathrm{pm}$ is potentially toxic and over 1800 ppm is very toxic. The aim of this study was investigation of HCN level in different growth stages of silage sorghum whether reach to harmful level for animals, and determination of the difference among varieties in terms of the HCN level. Moreover, the effect of first and second sowings and different harvesting heights on HCN levels were observed.

\section{MATERIALS AND METHODS}

The study was conducted in the experimental areas of Batı Akdeniz Agricultural Research Institute between 2014 and 2015. The experimental field was under Mediterranean climate that has hot and dry summers, and mild and rainy winters. The climate data of experimental area,maximum, minimum and average temperatures and rainfall for 2014, 2015 and long time were shown Table 4 The land where the research was conducted, have silty with clayey, saltless, very high limey, strong alkaline and low organic matter content soil. Rox, Gozde 80, Leoti, Early Sumac and Nes sorghum varieties, which are widely used in the Mediterranean region and registered by
BATEM, were used as plant material. The study was established in a randomized block design with three replications. In the first year, May-June and June-July planted crops were sowed in 07.05.2014 and 05.06.2014 respectively. In the second year May-June and June-July planted crops were sowed in 06.05.2015 and 07.06.2015 respectively. Sorghum seeds were sown in $3 \mathrm{~m}$ long plots with 8 rows. Row spacing and intrarow spacing were 45 $\mathrm{cm}$ and $10 \mathrm{~cm}$ respectively. Seeds were sown $2 \mathrm{~kg}$ per decare. In this experiment, $4 \mathrm{~kg} \mathrm{da}^{-1} 21 \%$ ammonium sulfate and $8 \mathrm{~kg} \mathrm{da}^{-1} 42 \%$ triple super phosphate were applied with sowing in both years. Any fertilizer treatments were not done throughout the growth season. Weed control was done manually in both years. The total rainfall received during the crop growth period (May-July) was 26.2 and $51.1 \mathrm{~mm}$ during 2014 and 2015, respectively. Irrigation was done in first sowing time in 08.06.2014, and second sowing time in 01.07.2014 for the first year. Furthermnore, it was done in first sowing time in 05.06.2014 and second sowing time in 30.06.2014 for the second year. After that, irrigation was not done until the end of the experiment. All other agronomic practices were done throughout the growing seasons. Plants were harvested at 40, 80 and $120 \mathrm{~cm}$ heights and extracted by compression machine. Harvesting times were shown in Table 5. HCN levels in the samples were determined using the colorimetric method that is suggested by Lambert et al. (1975) and adapted by Pirincci and Tanyıldız1 (1994). According to this method; calibration curve was prepared using by $0.05,0.1,0.2,0.3,0.4,0.5$, $0.6,0.8,1,2,3,4,5,6,8,10$ and $20 \mathrm{ppm}$ potassium cyanide solutions (Sigma-Aldrich Cat. No:31252-100 g). 1 ml water samples, $1 \mathrm{ml} \mathrm{N}$-chlorosuccinimide-succinimide solution (10 g succinimide Sigma-Aldrich Cat. No: 59381-500 $\mathrm{g}$ was dissolved in 200-300 ml distilled water, afterwards, $1 \mathrm{~g}$ N-chlorosuccinimide Sigma-Aldrich Cat. No: 109681-100 $\mathrm{g}$ was added and the solution was completed to the $1 \mathrm{lt}$ with distilled water) and $1 \mathrm{ml}$ barbituric acid-pyridine solution (3 g barbituric acid Sigma-Aldrich Cat. No:185698-25 $\mathrm{g}$ was dissolved in 10 $\mathrm{ml}$ distilled water, afterwards, $15 \mathrm{ml}$ pyridine SigmaAldrich Cat. No:360570-100 $\mathrm{ml}$ was added and the solution was completed to the $50 \mathrm{ml}$ with distilled water) were mixed and dropped to the $25 \mathrm{ml}$ flasks, afterwards, the solution was completed to the $25 \mathrm{ml}$ with distilled water. The solution was held on 15 minutes in the darkness for the colour formation. After that, $\mathrm{HCN}$ levels of the samples were determined as ppm by observation of absorbance in $575 \mathrm{~nm}$ in the spectrophotometer (Shimadzu, UV 1600) (Figure 1.). Obtained data in the experiment, was evaluated with analysis of variance by SAS (1998) statistical software. The differences between means were compared according to Duncan's multiple range test (Duzgunes et al., 1987). 


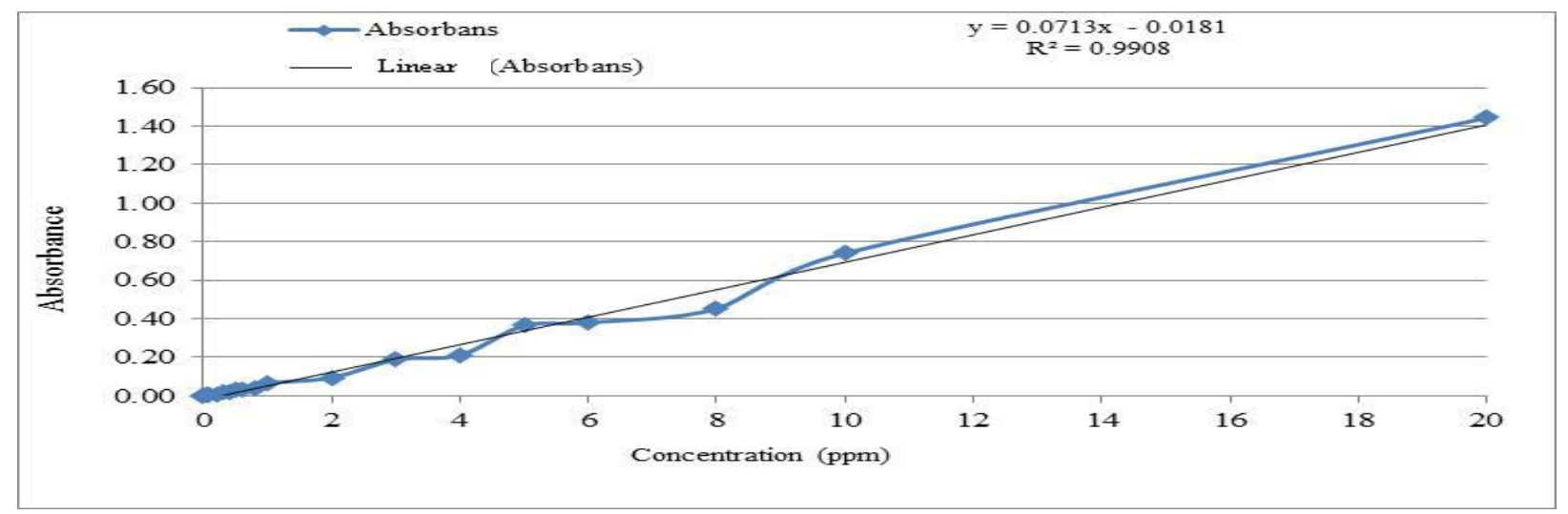

Figure 1. Calibration curve

\section{RESULTS AND DISCUSSION}

The analysis of variance for combined years showed that the variance was highly significant for HCN content, among the investigated characters. According to the results of analysis of variance at the 0.01 level; there was a significant difference between years, varieties, sowing times and harcesting heights. Moreover, there was a significant difference between year*variety, year*sowing time, year*harvesting height, variety*sowing time* harvesting height, year*variety*sowing time* harvesting height interactions (Table 1). Duncan test for means of HCN levels, which were obtained from using materials in the experiment, was shown at Table 2. It was observed that Gozde 80 sudangrass had the highest value with 8.26 ppm among the other varieties which had statistical difference in terms of HCN levels, and it was followed by Early Sumac with 6.60 ppm, Nes with 5.63 ppm, Leoti with $5.29 \mathrm{ppm}$ and Rox with $5.17 \mathrm{ppm}$. When means of HCN levels were examined according to sowing time; while HCN level was high with $7.36 \mathrm{ppm}$ at the first sowing time, it was $5.02 \mathrm{ppm}$ at the second sowing time. When HCN level was observed in terms of harvesting height, the average amounts were determined respectively as $8.99 \mathrm{ppm}, 5.66 \mathrm{ppm}, 3.93 \mathrm{ppm}$ while the harvesting heights were $40 \mathrm{~cm}, 80 \mathrm{~cm}, 120 \mathrm{~cm}$. By the reason of statistically differences between HCN levels in both years, the years were analyzed separately and grouped among themselves (Table 2).

Table 1. Variance analysis of HCN levels (Combined Years)

\begin{tabular}{|c|c|c|c|}
\hline Source of variation & d.f. & Sum of squares & F value \\
\hline Year & 1 & $793.6740050 * *$ & 4148.75 \\
\hline Blok(Year) & 4 & $0.3076000 \mathrm{NS}$ & 1.61 \\
\hline Variety & 4 & $59.4092256 * *$ & 310.55 \\
\hline Year*Variety & 4 & $27.3094411 * *$ & 142.75 \\
\hline Sowing time & 1 & $247.5968450 * *$ & 1294.25 \\
\hline Year* Sowing time & 1 & $27.5264006 * *$ & 143.89 \\
\hline Harvesting Height & 2 & $351.8564850 * *$ & 1839.25 \\
\hline Year*Harvesting Height & 2 & $22.6833450^{* *}$ & 118.57 \\
\hline Variety*Sowing Time*Harvesting Height & 22 & $8.1375691 * *$ & 42.54 \\
\hline Year* Variety*Sowing Time*Harvesting Height & 22 & $10.6688556 * *$ & 55.77 \\
\hline Error & 116 & 22.191333 & 0.19 \\
\hline
\end{tabular}

** Significant at 0.01 probability level. NS Non Significant

In the first year, while Early Sumac variety had the highest HCN level at the first sowing time with $40 \mathrm{~cm}$ harvesting height, Gozde 80 variety had the second highest $\mathrm{HCN}$ at the first sowing time with $40 \mathrm{~cm}$ harvesting height. Gozde 80 variety had the lowest level of $\mathrm{HCN}$ at the second sowing with $80 \mathrm{~cm}$ and $120 \mathrm{~cm}$ harvesting heights. Leoti, Nes and Rox varieties had 9.72 ppm, 5.69 ppm, $5.50 \mathrm{ppm}$ HCN levels respectively at the first sowing time with $40 \mathrm{~cm}$ harvesting height. While Gozde 80 variety had the highest HCN level with 6.62 ppm at the second sowing time with $40 \mathrm{~cm}$ harvesting height, HCN levels of Early Sumac, Rox, Nes and Leoti varieties were $4.61 \mathrm{ppm}, 4.32 \mathrm{ppm}, 2.41 \mathrm{ppm}$ and 2.35 ppm respectively (Table 2 ). 
Table 2. HCN content (ppm) of five silage sorghum varieties at the different sowing time and cutting heights

\begin{tabular}{|c|c|c|c|c|c|c|c|c|c|}
\hline \multirow[b]{2}{*}{ 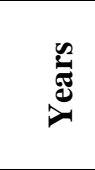 } & \multirow[b]{2}{*}{ Sowing time } & \multirow[b]{2}{*}{$\begin{array}{l}\text { Harvesting } \\
\text { height }\end{array}$} & \multicolumn{5}{|c|}{ Varieties } & \multirow[b]{2}{*}{$\begin{array}{l}\text { Mean } \\
\text { of } \\
\text { Year }\end{array}$} & \multirow[b]{2}{*}{$\mathbf{C V}$} \\
\hline & & & Gozde 80 & Early Sumac & Nes & Leoti & $\operatorname{Rox}$ & & \\
\hline \multirow{10}{*}{ 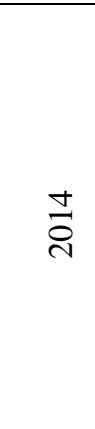 } & & 40 & $12.89 \mathrm{~b}$ & $14.15 \mathrm{a}$ & $5.69 \mathrm{e}$ & $9.72 \mathrm{c}$ & $5.50 \mathrm{e}$ & \multirow{7}{*}{$8.29 \mathrm{a}$} & \multirow{15}{*}{7.05} \\
\hline & First Sowing & 80 & $5.35 \mathrm{e}$ & $4.57 \mathrm{fg}$ & $4.40 \mathrm{~g}$ & $2.80_{1}$ & $3.69 \mathrm{~h}$ & & \\
\hline & & 120 & $3.48 \mathrm{~h}$ & $4.79 \mathrm{f}$ & 2.821 & $2.13 \mathrm{k}$ & 2.861 & & \\
\hline & & 40 & $6.62 \mathrm{~d}$ & $4.61 \mathrm{fg}$ & $2.41 \mathrm{jk}$ & $2.35 \mathrm{jk}$ & $4.32 \mathrm{~g}$ & & \\
\hline & Second Sowing Time & 80 & $1.17 \mathrm{~lm}$ & $3.58 \mathrm{~h}$ & 1.391 & 1.431 & 2.761 & & \\
\hline & & 120 & $0.96 \mathrm{~m}$ & $2.57 \mathrm{ij}$ & $1.22 \mathrm{~lm}$ & $1.27 \mathrm{~lm}$ & $1.27 \mathrm{~lm}$ & & \\
\hline & & 40 & $15.43 \mathrm{a}$ & $12.67 \mathrm{~b}$ & $11.25 \mathrm{~cd}$ & 10.37 & 10.77 & & \\
\hline & First Sowing & 80 & $10.60 \mathrm{~d}$ & $10.47 \mathrm{~d}$ & $8.16 \mathrm{f}$ & $6.87 \mathrm{gh}$ & $7.95 \mathrm{fg}$ & \multirow{5}{*}{4.09} & \\
\hline & & 120 & $7.86 \mathrm{fg}$ & $6.92 \mathrm{gh}$ & $7.31 \mathrm{fg}$ & $4.30 \mathrm{ij}$ & $5.20_{1}$ & & \\
\hline & & 40 & $14.83 \mathrm{a}$ & $7.75 \mathrm{fg}$ & $11.19 \mathrm{~cd}$ & $9.46 \mathrm{e}$ & $7.82 \mathrm{fg}$ & & \\
\hline \multirow{2}{*}{ in } & \multirow[t]{2}{*}{ Second Sowing Time } & 80 & $11.68 \mathrm{c}$ & $4.76 \mathrm{ij}$ & $7.53 \mathrm{fg}$ & $7.75 \mathrm{fg}$ & $6.25 \mathrm{~h}$ & & \\
\hline & & 120 & $8.25 \mathrm{f}$ & $2.41 \mathrm{k}$ & $4.16 \mathrm{ij}$ & 5.111 & $3.73 \mathrm{j}$ & & \\
\hline \multirow{2}{*}{\multicolumn{2}{|c|}{$\begin{array}{l}\text { Mean of Variety } \\
\text { Mean of Harvesting Height }\end{array}$}} & & $8.26 \mathrm{a}$ & $6.60 \mathrm{~b}$ & $5.63 \mathrm{c}$ & $5.29 \mathrm{~d}$ & \multicolumn{2}{|l|}{$5.17 \mathrm{~d}$} & \\
\hline & & & $40 \mathrm{~cm}: 8.9$ & & $80 \mathrm{~cm}: 5$. & & $120 \mathrm{~cm}:$ & $3.93 \mathrm{c}$ & \\
\hline \multicolumn{2}{|c|}{ Mean of Sowing Time } & & \multicolumn{2}{|c|}{$1^{\text {st }}$ Sowing Time: $7.36 \mathrm{a}$} & \multicolumn{4}{|c|}{$2^{\text {nd }}$ Sowing Time: $5.02 \mathrm{~b}$} & \\
\hline
\end{tabular}

Table 3. Safe Limits of HCN Concentration in Forage

\begin{tabular}{lrrrr}
\hline \multirow{2}{*}{ Relative degree of toxicity } & \multicolumn{2}{c}{$\begin{array}{c}\text { Concentration of HCN } \\
\text { in dry forage }\end{array}$} & \multicolumn{2}{c}{$\begin{array}{c}\text { Concentration of HCN } \\
\text { in fresh forage }\end{array}$} \\
\cline { 2 - 5 } & ppm & mg HCN/100 gm & ppm & mg HCN/100 gm \\
\hline Very low & -- & $0-25(0-0.025 \%)$ & -- & -- \\
Low & $0-500$ & $25-50(0.025-0.050 \%)$ & $<150$ & $<15$ \\
Medium (potential) & $500-700$ & $50-75(0.050-0.075 \%)$ & $150-200$ & $15-20$ \\
High (dangerous) & $>750$ & $>75(>0.750 \%)$ & $>200$ & $>20$ \\
\hline$*$ (Lang, 2001) & & &
\end{tabular}

Table 4. Climate Data (2014- 2015-Long Period)

\begin{tabular}{|c|c|c|c|c|}
\hline \multirow[b]{2}{*}{ Years } & \multirow[b]{2}{*}{ Climate data } & \multicolumn{3}{|c|}{ Months } \\
\hline & & May & June & July \\
\hline \multirow{4}{*}{$\stackrel{+}{\vec{d}}$} & $\begin{array}{l}\text { Precipitation }(\mathrm{mm}) \\
\end{array}$ & 27.2 & 0.0 & 0.0 \\
\hline & Mean Temp. $\left({ }^{\circ} \mathrm{C}\right)$ & 20.2 & 25.3 & 27.5 \\
\hline & Max Temp. $\left({ }^{\circ} \mathrm{C}\right)$ & 25.9 & 32.1 & 33.1 \\
\hline & Min Temp. $\left({ }^{\circ} \mathrm{C}\right)$ & 14.3 & 18.0 & 21.3 \\
\hline \multirow{4}{*}{$\stackrel{n}{\stackrel{2}{2}}$} & Precipitation (mm) & 46.0 & 5.0 & 1 \\
\hline & Mean Temp. $\left({ }^{\circ} \mathrm{C}\right)$ & 21.3 & 23.8 & 27.7 \\
\hline & Max Temp. $\left({ }^{\circ} \mathrm{C}\right)$ & 34.5 & 38.2 & 41.3 \\
\hline & Min Temp. $\left({ }^{\circ} \mathrm{C}\right)$ & 11.0 & 15.6 & 16.4 \\
\hline \multirow{4}{*}{ 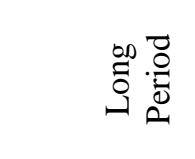 } & Precipitation (mm) & 31.8 & 7.9 & 3.0 \\
\hline & Mean Temp. $\left({ }^{\circ} \mathrm{C}\right)$ & 20.5 & 25.4 & 28.4 \\
\hline & Max Temp. $\left({ }^{\circ} \mathrm{C}\right)$ & 38.0 & 44.8 & 45.0 \\
\hline & Min Temp. $\left({ }^{\circ} \mathrm{C}\right)$ & 6.7 & 11.1 & 14.8 \\
\hline
\end{tabular}


Table 5. Harvesting Time

\begin{tabular}{|c|c|c|c|c|c|c|c|}
\hline \multirow{3}{*}{ Years } & \multirow{3}{*}{ Varieties } & \multirow{2}{*}{\multicolumn{3}{|c|}{$\begin{array}{c}\text { First Sowing Time } \\
\text { Harvesting height }(\mathrm{cm})\end{array}$}} & \multirow{2}{*}{\multicolumn{3}{|c|}{$\begin{array}{l}\text { Second Sowing Time } \\
\text { Harvesting height }(\mathrm{cm})\end{array}$}} \\
\hline & & & & & & & \\
\hline & & 40 & 80 & 120 & 40 & 80 & 120 \\
\hline \multirow{5}{*}{$\underset{⿱}{\vec{d}}$} & Gözde 80 & 18.06 .2014 & 25.06 .2014 & 01.07 .2014 & 11.07 .2014 & 17.07 .2014 & 24.07 .2014 \\
\hline & Nes & 11.06 .2014 & 18.06 .2014 & 26.06 .2014 & 04.07 .2014 & 11.07 .2014 & 21.07.2014 \\
\hline & Leoti & 19.06.2014 & 26.06.2014 & 04.07.2014 & 14.07.2014 & 21.07.2014 & 29.07.2014 \\
\hline & Rox & 11.06 .2014 & 17.06 .2014 & 25.06 .2014 & 07.07.2014 & 14.07.2014 & 21.07.2014 \\
\hline & $\begin{array}{l}\text { Early } \\
\text { Sumac }\end{array}$ & 11.06 .2014 & 18.06.2014 & 25.06.2014 & 04.07.2014 & 10.07.2014 & 18.07.2014 \\
\hline \multirow{5}{*}{$\frac{n}{2}$} & Gözde 80 & 15.06 .2015 & 23.06 .2015 & 30.06 .2015 & 08.07 .2015 & 14.07 .2015 & 19.07 .2015 \\
\hline & Nes & 10.06 .2015 & 16.06 .2015 & 24.06 .2015 & 02.07.2015 & 09.07.2015 & 19.07.2015 \\
\hline & Leoti & 17.06 .2015 & 24.06 .2015 & 30.06 .2015 & 14.07 .2015 & 19.07.2015 & 26.07.2015 \\
\hline & Rox & 10.06 .2015 & 15.06 .2015 & 23.06 .2015 & 06.07 .2015 & 12.07.2015 & 19.07.2015 \\
\hline & $\begin{array}{l}\text { Early } \\
\text { Sumac }\end{array}$ & 10.06 .2015 & 15.06.2015 & 22.06 .2015 & 01.07 .2015 & 07.07 .2015 & 15.07 .2015 \\
\hline
\end{tabular}

In the second year, while Gozde 80 variety had again the highest levels of $\mathrm{HCN}$ at the first sowing time with 80 $\mathrm{cm}$ harvesting height and at the second sowing time with $40 \mathrm{~cm}$ harvesting height, Early Sumac had the lowest amount of $\mathrm{HCN}$ with $120 \mathrm{~cm}$ harvesting height. At the first sowing time, Early Sumac, Nes, Rox and Leoti had $12.67 \mathrm{ppm}, 11.25 \mathrm{ppm}, 10.77 \mathrm{ppm}$ and $10.37 \mathrm{ppm} \mathrm{HCN}$ levels respectively with $40 \mathrm{~cm}$ harvesting height. At the second sowing time, $\mathrm{HCN}$ levels were $14.83 \mathrm{ppm}$ in Gozde 80, 11.19 ppm in Nes, 9.46 ppm in Leoti, $7.82 \mathrm{ppm}$ in Rox and $7.75 \mathrm{ppm}$ in Early Sumac with $40 \mathrm{~cm}$ harvesting height (Table 2). Studies for determination of the hydrocyanic acid amount in silage sorghum; Haque and Bradbury (2001) reported that while the HCN content was $740 \mathrm{ppm}$ at a week after the germination stage, it reduced to $160 \mathrm{ppm}$, after three weeks. Zahid et al. (2012) observed HCN contents 10 days, 40 days and 70 days after germination and, 6 hours, 12 hours and 18 hours after harvesting in three commonly grown sorghum varieties and one local variety. 10 days after germination HCN level was 723 ppm, 40 days after germination 209 ppm and 70 days germination it was $126 \mathrm{ppm}$. Furthermore, in local sorghum variety, 10 days after germination while HCN level was 723 ppm, 6 hours after harvesting $723 \mathrm{ppm}, 12$ hours after harvesting $658 \mathrm{ppm}$, and 18 hours after harvesting it was $637 \mathrm{ppm}$. As a result, HCN levels were very high at early growth stages of all varieties, however it reduced at following growth stages. In addition, Sarfraz et al. (2012) determined HCN levels of the varieties, which were used in the experiment, varied between 255.4 ppm (F-9601) and $346.6 \mathrm{ppm}$ (Hegari). Satpal Duhan et al. (2015) determined HCN content between 761.0 and 170.3 ppm. AL-Sultan (2003) determined $\mathrm{HCN}$ content as $0.698 \mathrm{ppm}$ when the plant height was $46 \mathrm{~cm}, 2.54 \mathrm{ppm}$ when it was $80 \mathrm{~cm}$, and 0.042 ppm when it was $120 \mathrm{~cm}$.

Shaug (1990) stated that HCN level was 0.1 - 55.9 ppm in sorghum bicolor lines, and it was 8.6-47.4 ppm in sudangrass at the flowering period. Sotomajor-Rios and Torres-Cardona (1984) were found lower HCN level at $60^{\text {th }}$ day than $45^{\text {th }}$ day in their study, which was about agronomic performance, $\mathrm{HCN}$ and heterosis of hybrid sorghum silage. Furthermore, they identified $191 \mathrm{ppm}$ HCN level in the male parents, which had a high yield potential. Torres et al. (1983) studied about HCN potential and agronomic performance of single and triplet hybrids of silage sorghum, and they observed that HCN level was more than $200 \mathrm{ppm}(250-285 \mathrm{ppm})$, which is a toxic for animals. In this study; it was observed that the amount of $\mathrm{HCN}$ was high at the early stages of plant growth and it was low at the following growth stages. Similarly, Haque and Bradbury (2001), Zahid et al. (2012), AL-Sultan (2003) and Sotomajor-Rios and Torres-Cardona (1984) stated that $\mathrm{HCN}$ level reduces in parallel with plant growth. HCN levels were different among varieties in this experiment, similarly Zahid et al. (2012) determined the difference among genotypes. HCN levels of the varieties used in this experiment were similar to HCN levels in the studies of Shaug (1990) and AL-Sultan (2003), and they were lower than in the studies of Haque and Bradbury (2001), Zahid et al. (2012), Satpal Duhan et al. (2015), Torres et al. (1983) and Sotomajor-Rios and TorresCardona (1984). The reason of the difference between the values, the difference of the genotypes and ecological conditions can be considered. At the same time, it can be said that physiological development period of the plant, temperature, drought, drugs and nitrogen fertilization, etc. had an effect on HCN content of sorghum (Tusuz et al., 1984; Langer and Hill 1982; Acrkgoz 2001).

In different studies for determination of the $\mathrm{HCN}$ levels in sorghum, it was emphasized that nitrogen manner increased the HCN level (Sher et al., 2012; Bahrani and Ghenateghestani, 2004; Wheeler et al., 1980; AbdelGowd. 2008), however, in this study this situation cannot be demonstrated due to no fertilizer treatment was done. Similarly; Vickery et al. (1987), and Wheeler et al. (1984) reported that temperature and precipitation effect on level of $\mathrm{HCN}$, in this study there was no precipitation during vegetation period, and no relation was found between temperature and $\mathrm{HCN}$ level. Irrigation was done only before the first harvesting, therefore, irrigation effect on $\mathrm{HCN}$ level could not be determined. For the future studies, the effect of irrigation and climatic conditions on $\mathrm{HCN}$ content should be done. 
The results of this study showed that the HCN levels in all silage sorghum and sudangrass varieties, in May-June and June-July planted crops and in all harvesting heights, were under the dangerous limit. There were statistically significant differences between the varieties in terms of $\mathrm{HCN}$ level. HCN levels were higher in the May-June planted crops than in the June-July planted crops, moreover, HCN levels was high at the beginning of the growth stage and it reduced in parallel with plant growth. It was observed that sorghum and sudangrass varieties, which were used in this experiment, did not contain $\mathrm{HCN}$ in a dangerous level for animals, and Leoti and Rox varieties had $\mathrm{HCN}$ in a lower levels. Moreover, all varieties had lower HCN level in 120 harvesting height and in June-July planted crops.

\section{LITERATURE CITED}

Ac1kgoz, E. 2001. Forage Plants. VIPAS Publication number 58, 584 p. Bursa.

FAO. 2017. Agricultural Statistics Database. Food and Agriculture Organization of United Nations, http://www.fao.org/faostat/en/data/QC Accessed date: 02 Fabruary 2017.

AL-Sultan, S.I. 2003. Sorghum halepenses and its cyanide content. Pakistan Journal of Nutrition (PJN). 2: 3 123-124,

Aziz-Abdel, T.K. and M.A.S. Abdel-Gwad. 2008. Yield and quality of tunis grass as affected by plant height at cutting and $\mathrm{N}$ fertilizer. Animal Agric. Sci. 53: 157-169.

Baytekin, H., V. Tans1 and T. Saglamtimur. 1996. The effect on amount of seed on hay yield and some agricultural characteristics of the silage sorghum varieties as second crop in Harran Plain in wet conditions. VII. Field Crops Congress in Turkey. Erzurum, 1: 753-760.

Bahrani, M.J. and A.D. Ghenateghestani, 2004. Summer forage sorghum yield, protein and prussic acid contents as affected by plant density and nitrogen top dressing. J. Agric. Sci. Technol., 6: 73-83

Cecen, S., M. Oten and C. Erdurmus. 2005. Assesment of sorghum (Sorghum bicolor L.), sudangrass (Sorghum sudanense L.) and corn (Zea mays L.) as second crop in the Coastal Region of West Mediterranean Belt of Turkey. Mediterr Agric Sci. 18:3 337-341.

Duzguneş, O., T. Kesici and F. Gunduz. 1987. Research and Trial Methods. Ankara University Faculty of Agriculture, Publication number: 1021 Textbook 295 Ankara.

Gul, I. and H. Baytekin. 1999. Investigation of yield and yield properties in silage sorghum, sorghumxsorghum sudangrass hybrids and sudangrass varieties as second crop in Diyarbakır wet conditions. VII. Field Crops Congress in Turkey, Adana. 3: 166-171.

Haque, R.M. and J.H. Bradbury. 2001. The total cyanide determination of plants and foods using the pictrate and acid hydrolysis methods. J. Food Chem. 17: 107-114.

Isakov, Y. I. and K. I. Basova. 1973. Contents of hydrocyanic acid in fresh fodder of sorghum. Trudy, Donskoi Zonal' nyi Institut Sel' skogo Khozyaistva 6: 28-29.

Karadas, S. 2008. Determination to yield and some yield component of sorgum sudangrass as second crops in different row spacing. Selcuk University Graduate School of Natural and Applied Sciences, Konya, Master's Thesis. 1842.

Koch, D.W. and S. Paisley. 2002. Managing forages to minimize nitrate poisoning. Univ. of Wyoming Cooperative Extension Publ. B-1122.7.
Lambert, L.J., J. Ramasamy and J.V. Paukstelis. 1975. Stable reagents for the colorimetric determination of cyanide by modified König Reaction. Anal Chem 47: 916-918.

Langer, R.H.M. and G.D. Hill. 1982. Agricultural Plants. Published by Cambridge University Press (1982) ISBN 10: 0521224500 ISBN 13: 9780521224505.

Lang, B. 2001. Sudan/Sorghum forage management. Iowa State University. University Extension. Fact Sheet BL-50, June 2001

McGinty, D.D. 1972. Sorghum in Animal Nutrition, Oxfort and IBH Publishing Co. 461-481.

Mulayim, M., A. Ozkose and S. II1k. 2009. Determination of yield and some agricultural characteristics on sorghum $\mathrm{x}$ hybrid cultivars in Konya conditions. VIII. Field Crops Congress in Turkey. Hatay 1: 627-630.

Okuyucu, F. 1975. Die reaktion von verschidenen sorghum sorten (Sorghum dochna Forsk. 'snowden') Auf tageslange und temperatur und deren auswirkungen auf die leistungsfahigkeit unter differenzierten klimabdingungen. Diss. Univ. Giessen.

Oten, M. and S. Cakmakc1. 2010. Determination of optimum seed sowing time for six different sorghum cultivars in purpose of silage production in Mediterrenean Coastline. Second Interneetional Symposium on Sustainable Development. June 8-9, 2010, Sarajevo. 1: 464 - 467

Pholsen, S. and N. Somsungnoen. 2004. Effect of nitrogen and potassium rates and planting distances on growth, yield and fodder quality of a forage sorghum (Sorghum bicolor L. Moench). Pak J Biol Sci. 7:10 1793-1800.

Pirincci, I. and S. Tany1ldizi. 1994. Determination of HCN levels in feeds. J. Vet. Sci. 10:1-2 84-89.

Sarfraz. M., N. Ahmad, U. Farooq, A. Ali and K. Hussain. 2012. Evaluation of sorghum varieties/lines for hydrocyanic acid and crude protein contents Agricultural Research Institute, Faisalabad, Pakistan. J. Agric. Res., 2012, 50(1)

SAS Institute. 1998. INC SAS/STAT users' guide release 7.0, Cary, NC, USA.

Satpal, Duhan, B.S., U.N. Joshı, A. S. Godara, S. Arya and Neelam. 2015. Response of yield, quality and economics of single cut forage sorghum genotypes to different nitrogen and phosphorus levels. Forage Res. 41: 3 170-175

Shaug, S.P. 1990. Studies on inheritance of hydrocyanic acid potential in forage sorghum. The variation and maternal effect of hydrocyanic acid potential in forage sorghum. J. Taiwan Livestock Res. 23:1 41-50.

Sher, A., M. Ansar, F.U. Hassan, G. Shabbir and M.A. Malik. 2012. Hydrocyanic acid contents variation amongst sorghum cultivars grown with varying seed rates and nitrogen levels. Int. J. Agric. Biol., 14: 720-726

Sotomajor Rios, A. and S. Torres Cardona. 1984. Agronomic performance, hyrocyanic acid potential $(\mathrm{HCN})$ and heterosis in forage sorghum hybrids. J Agric Univ Puerto Rico 68:2 131-141.

Soya, H. 1999. Cultivation of fodder crops as a second yield. Meadow management and breeding, Ministry of Agriculture and Rural Affairs, General Directorate of Agricultural Production and Development, Ankara, 93-103.

Torres-Cardon, S., A. Sotomajor-Rios and L. Telek. 1983. Agronomic performance and hydrocyanic acid potential (HCN-p) of single and three-way sorghum-forage hybrids and DeKalb hybrid SX-17. J Agric Univ PR 67:1 39-49.

Tugay, M. 2009. The effects of tillage and non-tillage on yield and quality of sorghum as second crops. Selçuk University Graduate School of Natural and Applied Sciences Department of Field Crops. Master's Thesis. 20-53.

Tusuz, M., N. Polat., F. Unal., G. Aydemir ve M. Ates. 1984. Silage sorghum cultivation in second crops. Publishing 
Project, Publications of Specialist, Ministry of Agriculture and Rural Affairs, General Directorate of Agricultural Production and Development.

Wheeler, J. L., C. Mulcahy., J.J. Walcott and G.G. Rapp. 1990. Factors affecting the hydrogen cyanide potential of forage sorghum. Australian J. Agric. Res 41: 1093-1100.

Vickery, P.J., J.L. Wheeler and C. Mulcahy. 1987. Factors affecting the hydrogen cynide potential of white clover (Trifolium repens L.) Aus. J. Agri. Res., 38: 1053-9.

Williams, M.C. and L.F. James. 1983. Effects of herbicides on the concentration of poisonous compounds in plants: a review. Am. J. Vet. Res. 44: 2420-2.
Y1lmaz, I. and I. Hosaflioglu, 2000. Possibilities of growing sorghum (Sorgum bicolor L. Moench) and sorghum $\mathrm{x}$ sudangras (Sorgum bicolor x Sorgum sudanense Stapf.) varieties as second crop. Chukurova University Journal of the Faculty of Agriculture 15:1 49-56.

Zahid, A., A. Khanum., M. Ansar and M.A. Malik. 2012. Effect of cutting and post-cutting intervals on hydrogen cyanide in sorghum forage grown under rain-fed conditions. Pak. J. Bot. 44:3 955-960. 